\title{
Article \\ Occurrence and Distribution of Strains of Saccharomyces cerevisiae in China Seas
}

\author{
Bai-Chuan Tian ${ }^{1}$, Guang-Lei Liu ${ }^{1,2} \mathbb{D}$, Zhe Chi $^{1} \mathbb{D}$, Zhong Hu ${ }^{3} \mathbb{D}$ and Zhen-Ming Chi ${ }^{1,2, *}$ \\ 1 College of Marine Life Sciences, Ocean University of China, Yushan Road, No. 5, Qingdao 266003, China; \\ m15634129717@163.com (B.-C.T.); liug1@ouc.edu.cn (G.-L.L.); cz1108@ouc.edu.cn (Z.C.) \\ 2 Laboratory for Marine Biology and Biotechnology, Qingdao National Laboratory for Marine Science \\ and Technology, Qingdao 266003, China \\ 3 Department of Biology, Shantou University, Shantou 515063, China; hzh@stu.edu.cn \\ * Correspondence: chi@ouc.edu.cn
}

Citation: Tian, B.-C.; Liu, G.-L.; Chi, Z.; Hu, Z.; Chi, Z.-M. Occurrence and Distribution of Strains of Saccharomyces cerevisiae in China Seas. J. Mar. Sci. Eng. 2021, 9, 590. https:// doi.org/10.3390/jmse9060590

Academic Editors: Casotti Raffaella and Concetta Gugliandolo

Received: 10 April 2021

Accepted: 26 May 2021

Published: 29 May 2021

Publisher's Note: MDPI stays neutral with regard to jurisdictional claims in published maps and institutional affiliations.

Copyright: (c) 2021 by the authors. Licensee MDPI, Basel, Switzerland. This article is an open access article distributed under the terms and conditions of the Creative Commons Attribution (CC BY) license (https:// creativecommons.org/licenses/by/ $4.0 /)$.
Abstract: The yeast Saccharomyces cerevisiae has been widely applied in fermentation industries, chemical industries and biological research and it is widespread in different environments, especially in sugar-rich environments. However, little is known about the occurrence, distribution and roles of S. cerevisiae in marine environments. In this study, only 10 strains among all the yeasts isolated from different marine environments belonged to $S$. cerevisiae. It was found that most of the strains of $S$. cerevisiae in marine environments occurred in guts, the surface of marine fish and mangrove trees. In contrast, they were not found in seawater and sediments. All the strains of $S$. cerevisiae isolated from the marine environments had a lower ability to produce ethanol than the highly alcohol-producing yeast Saccharomyces sp. W0 isolated from fermented rice, but the strains 2E00400, 2E00558, 2E00498, 2E00723, 2E00724 could produce higher concentrations of ethanol than any other marine-derived strains of $S$. cerevisiae obtained in this study. However, some of them had higher ethanol tolerance and higher trehalose content than Saccharomyces sp. W0. In particular, ethanol tolerance of the yeast strain 2E00498 was higher than that of Saccharomyces sp. W0. This may be related to the harsh marine environments from which they were isolated. Such yeast strains with higher alcohol tolerance could be used to further improve the alcohol tolerance of Saccharomyces sp. W0.

Keywords: marine environments; S. cerevisae; identification; ethanol production; alcohol endurance

\section{Introduction}

Just like its name, S. cerevisiae is a functionally heterotrophic colonizer of sugary substrates [1]. It has also been found that it plays an important role in the production of natural secondary metabolites, pectinase and glycosidase, the inhibitory effect on the growth of mycotoxin-producing fungi, the degradation of some fractions of kasein and $\mathrm{CO}_{2}$ evolution and has lipolytic, proteolytic and urease activities [2]. S. cerevisiae has been extensively applied in fermentation, food, chemical and pharmaceutical industries for a long time [2]. In order to produce a higher yield of ethanol and any other metabolites, it is important to screen and utilize highly alcohol-tolerant strains of $S$. cerevisiae from different environments, including marine environments [2].

It has been well documented that the oceans cover $71 \%$ of the surface of the Earth, and they contain abundant biotic resources, including marine yeasts, their functional genes, their metabolites and highly active enzymes [3]. In our previous investigations [4], strains of several yeast genera isolated from different marine environments included Rhodotorula spp., Rhodosporidium spp., Candida spp., Debaryomyces spp., Cryptococcus spp., Yarrowia lipolytica, Aureobasidium spp., Metschnikowia spp., Torulopsis spp., Pichia spp., Kluyveromyces spp., S. cereviaise, Williopsis spp., Pseudozyma spp., Hansenula spp., Trichosporon spp., Filobasidium spp., Leucosporidium spp. and many unidentified genera of yeast strains. Some psychrophilic yeasts such as Mrakia frigida, Guehomyces pullulans and Metschnikowia australis 
have also been found to be widely distributed in the sea sediment of Antarctica [5,6]. All these yeasts were obtained from samples of seawater, sediments, marine fish, marine algae and mangroves in the Yellow Sea, East China Sea, South China Sea, Pacific Ocean, Indian Ocean, Antarctica and deep sea. Nagahama [7] reported that there were around 30 yeast species isolated from sediment and invertebrates collected from deep-sea floors around the northwest Pacific Ocean. However, Saccharomyces spp. were not found in such deep-sea floors. It was also stated in his review article that $S$. cerevisiae did not occur in offshore, estuary and mangrove areas. In contrast, S. cerevisiae can be found in the gastrointestinal tract of healthy Oncorhynchus mykiss and colonize the intestine of rainbow trout and sea bass $[8,9]$. This may suggest that $S$. cerevisiae only grow and survive in environments rich in organic substances. Harsh marine environments are characterized by a lack of organic nutrients, low temperature, high pressure and high concentration of salts [3]. We think that such harsh environments may make $S$. cerevisiae develop some special properties, such as tolerance to stressful conditions [4]. Therefore, it may be possible to obtain strains of $S$. cerevisiae with high alcohol tolerance from marine environments. Thus, the main aims of this study are to survey the occurrence and distribution of $S$. cerevisiae in different marine environments in China in order to select the strains of $S$. cerevisiae with high alcohol tolerance for their application in alcohol industries and basic research in biotechnology.

\section{Materials and Methods}

\subsection{Yeast Strains}

Saccharomyces sp. W0, which is both a highly alcohol-producing and highly alcoholtolerant yeast strain, which was isolated from fermented rice and has been utilized for high ethanol production in our laboratory for over 20 years [10], was used as a representative of terrestrial yeasts in this study. Other strains of $S$. cerevisiae used in this study were isolated from different marine environments in China, as described below.

\subsection{Medium and Chemicals}

The medium for growth of the yeasts was a yeast-peptone-dextrose (YPD) medium (prepared with seawater or distilled water) containing $20.0 \mathrm{~g} \mathrm{~L}^{-1}$ glucose, $20.0 \mathrm{~g} \mathrm{~L}^{-1}$ peptone, $10.0 \mathrm{~g} \mathrm{~L}^{-1}$ yeast extract. The alcohol fermentation medium was a synthetic medium [11] supplemented with $200.0 \mathrm{~g} \mathrm{~L}^{-1}$ sucrose and $10.0 \mathrm{~g} \mathrm{~L}^{-1}$ ammonium sulfate. All the chemicals used in this study were purchased from Sinopharm Chemical Reagents Co. Ltd., Shanghai, China.

\subsection{Sampling}

Hypersaline seawater ( $1 \mathrm{~m}$ depth, $26^{\circ} \mathrm{C}, \mathrm{pH} 8.1$ and $15 \%$ salinity, March of 2004), sediments of the salterns ( $1 \mathrm{~m}$ depth, $26^{\circ} \mathrm{C}, \mathrm{pH} 8.1$ and $15 \%$ salinity, October of 2004), seawater, sediments, different species of marine animals and algae in the Yellow Sea, Bohai Sea, China East Sea and South China Sea $\left(10 \mathrm{~m}\right.$ depth, $15^{\circ} \mathrm{C}, \mathrm{pH} 8.1$ and $2.89 \%$ salinity, October of 2005) were collected. The roots, stems, branches, leaves, barks, fruits and flowers $\left(35^{\circ} \mathrm{C}\right.$, July of 2008) from 18 species of mangrove plants at 6 different places in Hainan, Guangdong and Fujian Provinces in China were also used as sources for yeast isolation in this study. At the same time, the roots, stems, branches, leaves, barks, fruits and flowers $\left(35^{\circ} \mathrm{C}\right.$, July of 2008) from Clerodendrum inerme, Cassytha filiformis L., Phragmites communis Trin., Pandanus tectorius and Pluchea indica Less that are the typical accompanying plant species distributed in the mangrove ecosystems mentioned above were also utilized as sources for yeast isolation in this study. The seawater and sediments $\left(35^{\circ} \mathrm{C}\right.$, July of 2008) in some of the mangrove ecosystems mentioned above were also collected for isolation of the yeasts.

\subsection{Isolation and Purification of Marine Yeasts}

First, all the marine animals, marine algae and the roots, stems, branches, leaves, barks, fruits and flowers from the different mangrove trees were surface disinfected using 
$70 \%(v / v)$ ethanol. Then, after collection and treatment of the samples, two milliliters of the seawater or $2.0 \mathrm{~g}$ of the sediments or $2.0 \mathrm{~g}$ of the disinfected roots, stems, branches, leaves, barks, fruits and flowers from different mangrove trees or $2.0 \mathrm{~g}$ of the skin, gills and contents of the gut from different marine animals or $2.0 \mathrm{~g}$ of the different marine algae were immediately suspended in $50.0 \mathrm{~mL}$ of the sterile YPD medium supplemented with $5.0 \mathrm{~g} \mathrm{~L}^{-1}$ chloramphenicol in a $250 \mathrm{~mL}$ shaking flask, respectively. Finally, all the flasks were aerobically cultivated at $25^{\circ} \mathrm{C}$ and $180 \mathrm{rpm}$ for five days. After suitable dilution of the cell cultures with sterile saline water, each dilute was evenly spread on a YPD plate with $5.0 \mathrm{~g} \mathrm{~L}^{-1}$ chloramphenicol and all the plates were incubated at $20-25^{\circ} \mathrm{C}$ for five days. Each colony from the plates was and purified and transferred to a YPD slant for further cultivation, respectively.

\subsection{Identification of the Yeasts}

Each colony obtained above was photographed and recorded. The cell morphology of each yeast strain on the YPD plate was observed and photographed under a microscope. The fermentation and assimilation tests for each yeast strain were performed using the methods described by Kurtzman and Fell [12]. At the same time, S. cerevisiae ATCC32703 was used as a type strain.

\subsection{DNA Extraction and PCR Reactions}

Each yeast strain obtained above was cultivated in the liquid YPD medium at $28^{\circ} \mathrm{C}$ and $180 \mathrm{rpm}$ for $20 \mathrm{~h}$. The total genomic DNA of each yeast strain was isolated and purified by using the methods described by Sambrook et al. [13]. Amplification and sequencing of the $26 \mathrm{~S}$ rDNA sequence from the genomic DNA of each yeast strain were performed according to the methods described by Sambrook et al. [13], Chi et al. [14] and Gao et al. [15]. The common primers for amplification of the $26 \mathrm{~S}$ rDNA from the DNA template of each yeast strain were used, the forward primer was NL-1 (5'-GCATATCAATAAGCGGAGGAAAAG$\left.3^{\prime}\right)$ and the reverse primer was NL-4 (5'-GGTCCGTGTTTCAAGACGG-3') [16]. The reaction system $(25.0 \mu \mathrm{L})$ was composed of $10 \times$ buffer $2.5 \mu \mathrm{L}$, dNTP $0.8 \mu \mathrm{mol} \mathrm{L}^{-1}, \mathrm{MgCl}_{2}$ $1.5 \mathrm{mmol} \mathrm{L}^{-1}$, NL-1 $0.5 \mu \mathrm{mol} \mathrm{L}^{-1}$, NL-4 $0.5 \mu \mathrm{mol} \mathrm{L}^{-1}$, Taq DNA polymerase $1.25 \mathrm{U}$, template DNA $1.0 \mu \mathrm{L}$ and $\mathrm{H}_{2} \mathrm{O} 16.6 \mu \mathrm{L}$. The conditions for the PCR amplification were as follows: initial denaturation at $94{ }^{\circ} \mathrm{C}$ for $10 \mathrm{~min}$, denaturation at $94{ }^{\circ} \mathrm{C}$ for $1 \mathrm{~min}$, annealing temperature at $53{ }^{\circ} \mathrm{C}$ for $1 \mathrm{~min}$, extension at $72{ }^{\circ} \mathrm{C}$ for $2 \mathrm{~min}$, final extension at $72{ }^{\circ} \mathrm{C}$ for $10 \mathrm{~min}$. PCR was run for 30 cycles and the PCR cycler was the Mastercycler gradient thermal cycler made by Eppendorf. The obtained PCR products were separated by agarose gel electrophoresis and purified by using TAKARA DNA gel purification kits (TAKARA, Japan). The purified PCR products from each DNA template were ligated into the pMD-19T vector and the recombinant plasmid was transformed into the competent cells of Escherichia coli $\mathrm{DH} 5 \alpha$. The transformants obtained were selected on LB plates supplemented with ampicillin. The plasmids in the transformant cells were extracted by using the TIANGEN plasmids extraction kits (TIANGEN, Beijing, China). The 26S rDNA fragments inserted in the vector were sequenced by Shanghai Sangon.

\subsection{Phylogenetic Analysis}

The $26 \mathrm{~S}$ rDNA sequences obtained above were aligned by using BLAST analysis (http:/ / www.ncbi.nlm.nih.gov/BLAST, 20 May 2010). The sequences which shared over $98 \%$ similarity with the currently available $26 \mathrm{~S}$ rDNA sequences of fungi were considered to be the same species and multiple alignments were performed by using ClustalX 1.83 and the phylogenetic tree was constructed by neighbor-joining using MEGA 4.0 [17].

\subsection{Alcohol Fermentation Tests}

Each yeast strain of $S$. cerevisiae obtained above was grown aerobically at $30^{\circ} \mathrm{C}$ and $180 \mathrm{rpm}$ in synthetic medium [11] with $20.0 \mathrm{~g} \mathrm{~L}^{-1}$ sucrose and $10.0 \mathrm{~g} \mathrm{~L}^{-1}$ ammonium sulfate for $18 \mathrm{~h}$. Around $3 \times 10^{8}$ cells mL $\mathrm{mL}^{-1}$ in $15.0 \mathrm{~mL}$ of the fresh culture were collected by 
centrifugation at $4000 \times g$ and $4{ }^{\circ} \mathrm{C}$ for $5 \mathrm{~min}$. The collected cells were transferred to a $300 \mathrm{~mL}$ bottle with $150.0 \mathrm{~mL}$ of the synthetic medium containing $200.0 \mathrm{~g} \mathrm{~L}^{-1}$ sucrose and $10.0 \mathrm{~g} \mathrm{~L}^{-1}$ ammonium sulfate and the final concentration of the yeast cells was $3 \times 10^{7}$ cells $\mathrm{mL}^{-1}$ of the fermentation medium. Each bottle was fitted with a rubber bung perforated by a needle and incubated statically at $30{ }^{\circ} \mathrm{C}$. The loss of weight by $\mathrm{CO}_{2}$ liberation during the fermentation was monitored each day until the fermentation ceased. As the fermentation proceeded, additional sucrose (around $5.0 \mathrm{~g}$ per $100 \mathrm{~mL}$ of the fermentation medium) was added to keep a suitable concentration of sucrose in the medium. The final alcohol concentration in the fermented media was analyzed as described below.

\subsection{Ethanol Shock Treatment}

Each yeast strain of $S$. cerevisiae obtained above was inoculated into the YPD medium and cultivated at $30^{\circ} \mathrm{C}$ and $180 \mathrm{rpm}$ for $18 \mathrm{~h}$ as described above. The yeast cells from the culture $\left(1 \times 10^{8}\right.$ cells $\left.\mathrm{mL}^{-1}\right)$ were harvested by centrifugation and washed three times with sterile saline water. The washed cells were resuspended in $8.2 \mathrm{~mL}$ of sterile saline water and $1.8 \mathrm{~mL}$ of absolute ethanol was added to the cell suspension. Then, the cell suspensions were mildly shaken at $50 \mathrm{rpm}$ in a water bath $\left(30^{\circ} \mathrm{C}\right)$. During the high ethanol shock treatment, the treated samples were taken periodically from the cell suspension and the cell viabilities were determined following appropriate dilutions of the cultures and plating the dilute on YPD plates. Each strain on the plates was grown at $30^{\circ} \mathrm{C}$ for $48 \mathrm{~h}$ or $72 \mathrm{~h}$ and the colonies appeared on each plate were counted after 48 or $72 \mathrm{~h}$ incubation at $30^{\circ} \mathrm{C}$. All the plates were run in duplicate, with the results averaged for each duplication. Alcohol tolerance expressed as the percentage of the yeast survivors was determined by comparing the colony count of the ethanol-shocked cells with that of non-shocked controls [10]. The non-treated cells of the same strain were used as the control.

\subsection{Ethanol Assay}

One hundred milliliters of the fermented culture obtained above and $100.0 \mathrm{~mL}$ of distilled water were well mixed together. The mixture was distilled at $100{ }^{\circ} \mathrm{C}$ and $100 \mathrm{~mL}$ of the distillate was harvested. The distillate was diluted 1000-fold. The ethanol concentrations in the dilute and the standard ethanol solution were measured by using gas chromatography (HP5890II, Hewlett-Packard, USA). The chromatography column was a fused silica AC-20 capillary column ( $30 \mathrm{~m} \times 0.25 \mathrm{~mm}$ i.d., $0.25 \mathrm{~m}$ film thickness). The GC conditions used were previously described by Wang et al. [18].

\subsection{Trehalose Extraction and Assay}

Each yeast strain obtained above was inoculated into the liquid YPD medium and cultivated at $30{ }^{\circ} \mathrm{C}$ for $18 \mathrm{~h}$ by shaking at $180 \mathrm{rpm}$. All the yeast cells in $5.0 \mathrm{~mL}$ of the culture were collected and washed by centrifugation at $5000 \times g$ and $4{ }^{\circ} \mathrm{C}$. All the trehalose in the washed yeast cells of each yeast strain was extracted three times with $0.5 \mathrm{M}$ of trichloroacetic acid [19] and the amount of the extracted trehalose was assayed by using the anthrone method [19]. Finally, trehalose content per $100 \mathrm{~g}$ of cell dry weight was calculated based on the cell dry weight in $5.0 \mathrm{~mL}$ of the culture and was determined as described below.

\subsection{Measurement of Cell Dry Weight}

The yeast cells from $5.0 \mathrm{~mL}$ of the culture of each yeast strain were harvested and washed three times with sterile saline water by centrifugation at $4000 \times g$ for $5 \mathrm{~min}$. Then, all the washed yeast cells in each centrifuge tube were dried at $100{ }^{\circ} \mathrm{C}$ until the cell dry weight was constant.

\subsection{Statistical Analysis}

The data obtained above were subjected to one-way analysis of variance (ANOVA) [20]. $P$ values were calculated by a Student's $t$-test $(n=3) . p$ values less than 0.05 were considered 
statistically significant. Statistical analysis was performed using a SPSS 11.5 for Windows (SPSS Inc., Chicago, IL, USA).

\section{Results}

\subsection{Occurrence and Distribution of S. cerevisiae in China Seas}

In this study, over 1051 yeast strains were obtained from the different marine environments (http://www.mccc.org.cn, 2 October 2009). After the identification of the marine-derived yeasts by using conventional and molecular methods, we found that only 17 strains were strains of $S$. cerevisiae (Tables 1 and 2 and Figure 1). The results in Table 1 show that most of them were isolated from skin, gills and contents of the gut and stomach of different species of marine fish in the East China Sea and Bohai Sea. Only the strain 2E00396 was obtained from the surface of Laminaria japonica collected from the Bohai Sea and the strain 2E00977 was obtained from the leaf surface of Aegiceras in the South China Sea. It was strange that no strains of $S$. cerevisiae were found in the marine fish and marine algae collected in the Yellow Sea, or the seawater, sediments and salterns obtained in all China seas.

Table 1. The strains of S. cerevisiae isolated from China seas.

\begin{tabular}{|c|c|c|}
\hline Strains & Strain Sources and Sampling Sites & Latitude and Longitude \\
\hline 2E00396 & Laminaria japonica, Bohai Sea & $37^{\circ} 30^{\prime} \mathrm{N} 122^{\circ} 10^{\prime} \mathrm{E}$ \\
\hline 2E00400 & Stomach of Scomberomorus niphonius, Bohai Sea & $37^{\circ} 30^{\prime} \mathrm{N} 122^{\circ} 10^{\prime} \mathrm{E}$ \\
\hline 2E00498 & Gill of Pseudosciaena crocea, Bohai Sea & $37^{\circ} 30^{\prime} \mathrm{N} 122^{\circ} 10^{\prime} \mathrm{E}$ \\
\hline 2E00550 & Gill of Acanthopagrus schlegel, Bohai Sea & $37^{\circ} 30^{\prime} \mathrm{N} 122^{\circ} 09^{\prime} \mathrm{E}$ \\
\hline 2E00558 & Gill of Pampus argenteus, Bohai Sea & $37^{\circ} 30^{\prime} \mathrm{N} 122^{\circ} 08^{\prime} \mathrm{E}$ \\
\hline 2E00561 & Skin of Pampus argenteus, Bohai Sea & $38^{\circ} 44^{\prime} \mathrm{N} 118^{\circ} 49^{\prime} \mathrm{E}$ \\
\hline 2E00564 & Gill of Gobio gobio, Bohai Sea & $38^{\circ} 44^{\prime} \mathrm{N} 118^{\circ} 49^{\prime} \mathrm{E}$ \\
\hline 2E00656 & Skin of Pseudosciaena polyactis, Bohai Sea & $38^{\circ} 44^{\prime} \mathrm{N} 118^{\circ} 49^{\prime} \mathrm{E}$ \\
\hline 2E00723 & Stomach of Acanthogobius flavimanus, Bohai Sea & $37^{\circ} 30^{\prime} \mathrm{N} 122^{\circ} 09^{\prime} \mathrm{E}$ \\
\hline 2E00724 & Digestive canals of Paralichthys olivaceus, Bohai Sea & $37^{\circ} 30^{\prime} \mathrm{N} 122^{\circ} 08^{\prime} \mathrm{E}$ \\
\hline 2E00977 & Leaf surface of Aegiceras, South China sea & $21^{\circ} 07^{\prime} \mathrm{N} 110^{\circ} 45^{\prime} \mathrm{E}$ \\
\hline 2E01006 & Gill of horsemackerel, East China Sea & $24^{\circ} 26^{\prime} \mathrm{N} 118^{\circ} 02^{\prime} \mathrm{E}$ \\
\hline 2E01007 & Stomach of Dasyatis akaje, East China Sea & $24^{\circ} 26^{\prime} \mathrm{N} 118^{\circ} 02^{\prime} \mathrm{E}$ \\
\hline 2E01008 & The skin of Goblet, East China Sea & $24^{\circ} 26^{\prime} \mathrm{N} 118^{\circ} 02^{\prime} \mathrm{E}$ \\
\hline 2E01009 & The skin of Muraenesox cinereus, East China Sea & $24^{\circ} 26^{\prime} \mathrm{N} 118^{\circ} 02^{\prime} \mathrm{E}$ \\
\hline 2E01010 & Intestine of Stephanolepis cirrhife, East China Sea & $24^{\circ} 26^{\prime} \mathrm{N} 118^{\circ} 02^{\prime} \mathrm{E}$ \\
\hline 2E01011 & Stomach of Saurida elongate, East China Sea & $24^{\circ} 26^{\prime} \mathrm{N} 118^{\circ} 02^{\prime} \mathrm{E}$ \\
\hline
\end{tabular}

Table 2. Results of carbohydrate fermentation tests and carbon assimilation of the marine yeasts.

\begin{tabular}{|c|c|c|c|c|c|c|}
\hline & 2E00396 & 2E00400 & 2E00498 & 2E00550 & 2E00558 & 2E00561 \\
\hline \multicolumn{7}{|l|}{ Fermentation } \\
\hline Glucose & + & + & + & + & + & + \\
\hline Maltose & + & - & + & + & + & - \\
\hline Galactose & + & - & + & + & + & + \\
\hline Sucrose & + & + & + & + & + & + \\
\hline Lactose & - & - & - & - & - & - \\
\hline Raffinose & + & + & + & + & + & + \\
\hline \multicolumn{7}{|l|}{ Assimilation } \\
\hline Glucose & + & + & + & + & + & + \\
\hline Maltose & + & + & + & + & + & + \\
\hline Galactose & + & - & + & + & + & + \\
\hline Sucrose & + & + & + & + & + & + \\
\hline Lactose & - & - & - & - & - & - \\
\hline Raffinose & + & + & + & + & + & + \\
\hline Melibiose & - & - & - & - & - & - \\
\hline Amidulin & - & - & - & - & - & - \\
\hline Trehalose & + & - & + & + & + & + \\
\hline
\end{tabular}


Table 2. Cont.

\begin{tabular}{|c|c|c|c|c|c|c|}
\hline & 2E00396 & 2E00400 & 2E00498 & 2E00550 & 2E00558 & 2E00561 \\
\hline Cellobiose & - & $+/ \mathrm{W}$ & - & - & - & - \\
\hline D-arabinose & - & $\mathrm{W} / \mathrm{W}$ & - & - & - & - \\
\hline Xylose & - & W & - & - & - & - \\
\hline \multirow[t]{2}{*}{ L-arabinose } & - & - & - & - & - & - \\
\hline & 2E00564 & 2E00656 & 2E00723 & 2E00724 & 2E00977 & 2E001006 \\
\hline \multicolumn{7}{|l|}{ Fermentation } \\
\hline Glucose & + & + & + & + & + & + \\
\hline Maltose & + & - & + & + & + & - \\
\hline Galactose & + & - & - & + & + & - \\
\hline Sucrose & + & + & + & + & + & + \\
\hline Lactose & - & - & - & - & - & - \\
\hline Raffinose & + & + & + & + & + & + \\
\hline \multicolumn{7}{|l|}{ Assimilation } \\
\hline Glucose & + & + & + & + & + & + \\
\hline Maltose & + & + & + & + & + & + \\
\hline Galactose & + & - & + & - & + & - \\
\hline Sucrose & + & + & + & + & + & + \\
\hline Lactose & - & - & - & - & - & - \\
\hline Raffinose & + & + & + & + & + & + \\
\hline Melibiose & - & - & - & - & - & - \\
\hline Amidulin & - & - & - & - & - & - \\
\hline Trehalose & + & - & + & + & + & + \\
\hline Cellobiose & - & W & - & - & - & - \\
\hline D-arabinose & - & - & - & - & - & - \\
\hline Xylose & - & - & - & - & - & - \\
\hline L-arabinose & - & - & - & - & - & - \\
\hline KERRYPNX & 2E01007 & 2E01008 & 2E01009 & 2E01010 & 2E01011 & $\begin{array}{l}\text { S. cerevisiae } \\
\text { ATCC } 32703\end{array}$ \\
\hline \multicolumn{7}{|l|}{ Fermentation } \\
\hline Glucose & + & + & + & + & + & + \\
\hline Maltose & + & - & + & + & + & - \\
\hline Galactose & + & - & - & + & + & - \\
\hline Sucrose & + & + & + & + & + & + \\
\hline Lactose & - & - & - & - & - & - \\
\hline Raffinose & + & + & + & + & + & + \\
\hline \multicolumn{7}{|l|}{ Assimilation } \\
\hline Glucose & + & + & + & + & + & + \\
\hline Maltose & + & + & + & + & + & + \\
\hline Galactose & + & - & + & - & + & - \\
\hline Sucrose & + & + & + & + & + & + \\
\hline Lactose & - & - & - & - & - & - \\
\hline Raffinose & + & + & + & + & + & + \\
\hline Melibiose & - & - & - & - & - & - \\
\hline Amidulin & - & - & - & - & - & - \\
\hline Trehalose & + & - & + & + & + & + \\
\hline Cellobiose & - & W & - & - & - & - \\
\hline D-arabinose & - & - & - & - & - & - \\
\hline Xylose & - & - & - & - & - & - \\
\hline L-arabinose & - & - & - & - & - & - \\
\hline
\end{tabular}




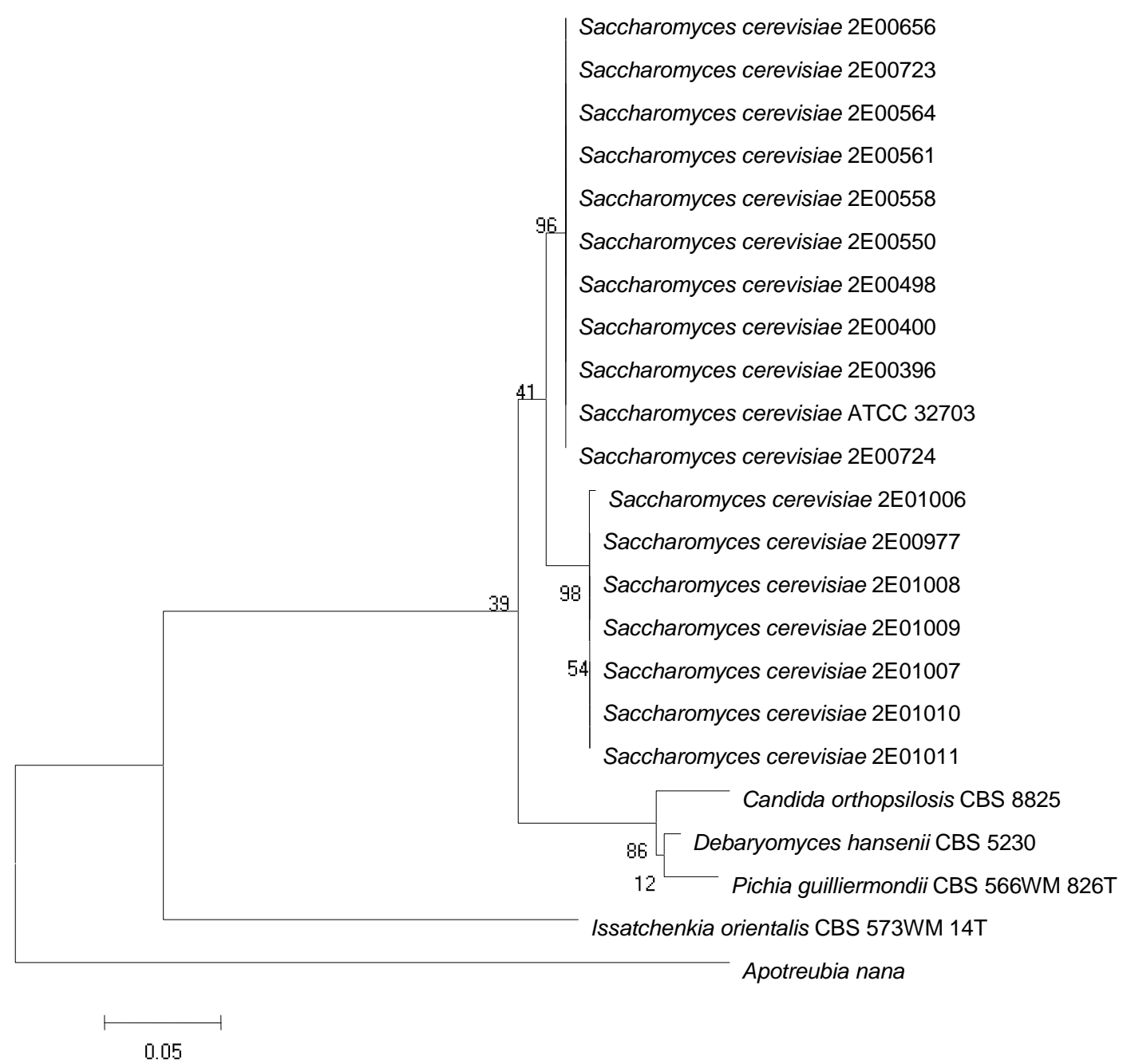

Figure 1. Phylogenetic tree of 17 strains of S. cerevisiae isolated in this study and 13 closest relatives based on a maximum parsimony analysis of D1/D2 26S rDNA sequences. Bootstrap values (1000 pseudoreplications) of $\geq 46 \%$. All the strains shown are type strains and Yarrowia lipolytica was used as the out-group.

\subsection{Alcohol Production}

In this laboratory, Saccharomyces sp. W0 has been shown to produce over $15 \%(v / v)$ ethanol from sucrose and the hydrolysate of corn starch for a long time [21,22]. After determination of alcohol concentration in the fermented media by the 17 strains and Saccharomyces sp. W0, we found that only strains 2E00400, 2E00558, 2E00498, 2E00723, 2E00724 and W0 could produce a high concentration of ethanol (Figure 2) and any other strains of $S$. cerevisiae isolated in this study yielded less ethanol than them (data not shown). The results in Figure 2 show that the loss of weight by $\mathrm{CO}_{2}$ liberation by the strains 2E00400, 2E00558, 2E00498, 2E00723 and 2E00724 during the fermentation, especially after $5 \mathrm{~d}$ of the fermentation, was lower than that by Saccharomyces sp. W0. The final alcohol concentrations produced by Saccharomyces sp. W0 were also higher than those produced by the strains 2E00400, 2E00558, 2E00498, 2E00723 and 2E00724. After the ANOVA analysis as described in the Materials and Methods, it was found that there were significant differences $(p=0.015)$ in the alcohol yield between Saccharomyces sp. W0 and all other yeast strains used in this study (data not shown). For example, Saccharomyces sp. W0 could produce $15.2 \%(v / v)$ ethanol while the strains 2E00400, 2E00558, 2E00498, 2E00723 and 2E00724 only produced $13.8 \%(v / v), 13.9 \%(v / v), 14.2 \%(v / v), 13.9 \%(v / v)$ and $14.0 \%(v / v)$ ethanol, respectively (data not shown). However, after the ANOVA analysis, it was found that there were no 
significant differences $(p>0.015)$ in the ethanol yields between 2E00400, 2E00558, 2E00498, 2E00723 and 2E00724 (data not shown).

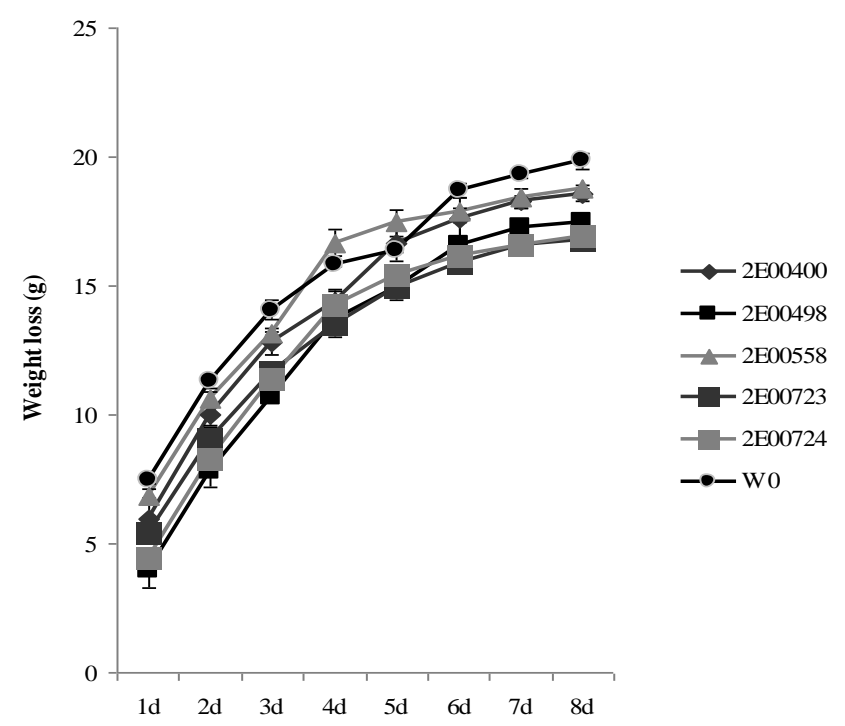

Figure 2. $\mathrm{CO}_{2}$ liberation by fermentation of different yeast strains grown in the synthetic media containing $200.0 \mathrm{~g} \mathrm{~L}^{-1}$ sucrose. Data are given as means $\pm \mathrm{SD}, n=3$. All the experiments were done in triplicate, with the results averaged for each experiment.

\subsection{Alcohol Tolerance}

All the yeast strains tested in this study were grown in the YPD medium for $18 \mathrm{~h}$ and their cells were washed by centrifugation as described in the Materials and Methods. The washed cells were treated with an 18.0\% $(v / v)$ ethanol solution and cell survival was determined as described in the Materials and Methods. The results in Figure 3 indicated that greater cell survival of the yeast strain 2E00498 was observed than that of Saccharomyces $\mathrm{sp}$. W0 within the first two hours of the ethanol shock treatment, although the latter could produce more ethanol than the former (Figure 2). For example, only 39\% of the cells of Saccharomyces sp. W0 survived within the first two hours of the ethanol shock treatment while the strain 2E00498 maintained 51\% survivors under the same conditions. This meant that the alcohol tolerance of the yeast strain 2E00498 isolated from the gills of $P$. crocea in the Bohai Sea (Table 1) was higher than that of Saccharomyces sp. W0, as supported by the ANOVA analysis ( $p=0.015$, differences were significant).

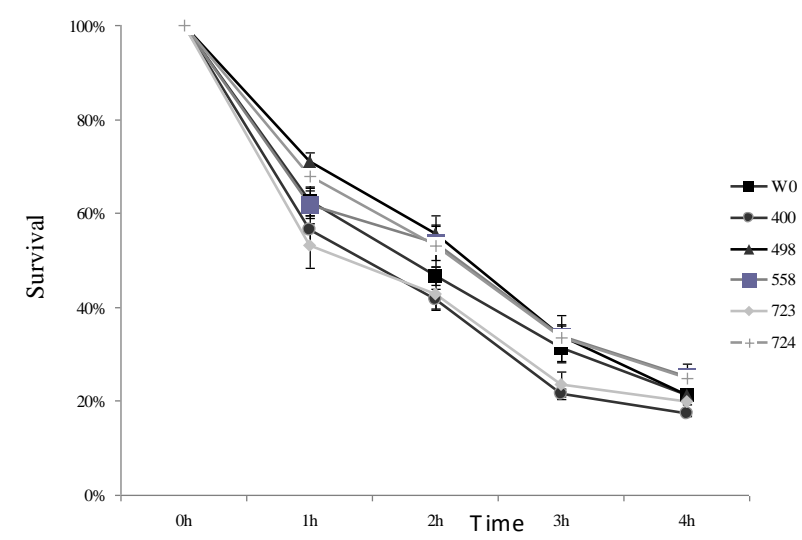

Figure 3. Cell survival (\%) of different yeast strains during the high ethanol shock treatment. Data are given as means $\pm \mathrm{SD}, n=3$.

It was found that that trehalose contents in the cells of many yeast strains isolated from marine environments, especially the yeast strain 2E00498, were also higher than those 
in the cells of Saccharomyces sp. W0, as supported by the ANOVA analysis ( $p=0.015$, differences were significant) (data not shown).

\section{Discussion}

It has been well evidenced that different strains of $S$. cerevisiae can grow and survive in media rich in organic substances, such as the surfaces of the fruits of most species of plants and naturally fermented media [2]. Therefore, it is not surprising that most of the strains of $S$. cerevisiae obtained in this study were widely distributed in skin, gills and contents of the gut and stomach of different species of marine fish rich in organic substances (Table 1). Gatesoupe [8] reported that Rhodotorula sp. seemed relatively frequent in both marine and freshwater fish, and Debaryomyces hansenii has been found to be a main group in rainbow trout, but $S$. cerevisiae was not found in the marine samples. Other yeasts such as Metschnikowia zobelii, Trichosporon cutaneum and Candida tropicalis in marine fish, and Candida sp., S. cerevisiae and Leucosporidium sp. in rainbow trout, were also the dominant yeast populations. S. cerevisiae was obtained from marine invertebrates such as Neoteredo reynei (shipworm), Anomalocardia brasiliana (clam) and Tagelus plebeius (clam) in the southeast mangrove ecosystems in Brazil [23]. However, although the extreme diversity of yeast communities occurred in polluted estuary and mangrove ecosystems in subtropical marine, offshore and deep-sea environments, S. cerevisiae was not isolated in such environments, either [7]. Moreover, it is interesting to note from the results in Table 1 that all the strains of S. cerevisiae were isolated from only the samples of the Bohai Sea, the South China Sea and the East China Sea and no strain of S. cerevisiae was found in the samples of the Yellow Sea. In addition, it can also be clearly observed from the results in Figure 1 that all the yeast strains isolated from the Bohai Sea were clustered together into one group while 2E001006, 2E001007, 2E001008, 2E001009, 2E001010 and 2E001011 isolated from the East China Sea and only 2E000977 isolated from the South China Sea were clustered together into the same group. This may be due to the fact that the East China Sea and South China Sea may be suitable for growth of S. cerevisiae while the conditions and environments in the Yellow Sea are not suitable for the growth of $S$. cerevisiae. This was why no strain of $S$. cerevisiae was found in the samples of the Yellow Sea. This may imply that such geographical separation could produce a specific distribution of S. cerevisiae in marine environments. However, two marine yeast strains (S69 and S71) of S. cerevisiae were obtained from seawater from Plymouth, UK [24]. At the same time, two marine strains (S117 and S118) of S. cerevisiae were also found in rotten seaweed from Plymouth, UK [24]. S. cerevisiae C19 was isolated from Tokyo Bay by Obara et al. [25]. This means that the environmental conditions in the China Sea are different from those in any other sea in the world.

We found that only strains 2E00400, 2E00558, 2E00498, 2E00723 and 2E00724 could produce higher concentrations of ethanol than any other strains of $S$. cerevisiae obtained in this study (Figure 2). Although the five yeast strains isolated from marine environments could produce high concentrations of alcohol from sucrose, their ability to produce alcohol was lower than that of Saccharomyces sp. W0 which was isolated from fermented rice [11]. This means that Saccharomyces sp. W0 is indeed a good producer of ethanol. According to the sources of the five yeast strains isolated from the marine environments (Table 1), it can be clearly observed that all of them were obtained from different parts of marine fish collected from the Bohai Sea. However, all the strains of S. cerevisiae isolated from the East China Sea and the South China Sea produced lower concentrations of ethanol than the five yeast strains isolated from the Bohai Sea. Thus far, it is completely unknown why all the strains of S. cerevisiae isolated from the East China Sea and the South China Sea produce lower concentrations of ethanol than the five yeast strains isolated from the Bohai Sea. Therefore, more strains of $S$. cerevisiae need to be isolated from the seas to confirm this in the future.

It was found that the marine-derived yeast $S$. cerevisiae AZ65 isolated from seawater of the English Channel, Plymouth, UK could produce $11.4 \mathrm{~g}$ ethanol per $100 \mathrm{~mL}$ of fermented 
medium using seawater-YPD medium and yielded $5.0 \mathrm{~g}$ ethanol per $100 \mathrm{~mL}$ of fermented medium using seawater-molasses medium [26]. Furthermore, the same marine-derived yeast S. cerevisiae AZ65 produced $97.0 \mathrm{~g} \mathrm{~L}^{-1}$ ethanol from a glucose-based medium in a $15 \mathrm{~L}$ fermentor [27]. A marine-derived strain (JN387604) of S. cerevisiae that was obtained from mangrove soil on the southeast coast of India had higher bioethanol production (4.8 $\mathrm{mg} \mathrm{L}^{-1}$ of ethanol) from $6.84 \mathrm{mg} \mathrm{L}^{-1}$ of sawdust than a terrestrial strain [28]. However, the amount of ethanol produced by the marine-derived strain (JN387604) was too low, so the technique was meaningless. The S. cerevisiae C19 strain isolated from Tokyo Bay yielded $123.0 \mathrm{~g} \mathrm{~L}^{-1}$ and $88.0 \mathrm{~g} \mathrm{~L}^{-1}$ of bioethanol from a concentrated paper shredder scrap hydrolysate and a mixture of seaweed hydrolysate (Undaria pinnatifida) and shredded paper, respectively $[25,28]$. This demonstrated that the marine-derived $S$. cerevisiae obtained in this study could produce a high ethanol concentration compared to any other marine-derived S. cerevisiae isolated from any other seas in the world (Figures 2 and 3).

The yeast cells of the strain 2E00498 also contained more trehalose than those of Saccharomyces sp. W0 (data not shown), suggesting that trehalose was involved in alcohol tolerance and some marine-derived yeast strains isolated from harsh environments indeed contained a high content of trehalose. This may partially explain why the alcohol tolerance of the yeast strain 2E00498 was higher than that of Saccharomyces sp. W0 (Figure 3). It has been well documented that trehalose in yeast cells can be involved in alcohol tolerance and other stress tolerances. This is due to the fact that trehalose in yeast cells can function as a highly efficient protectant for biological macromolecules such as proteins, enzymes and DNA, enhancing the resistance of the key cellular components against various harsh conditions such as high and cold temperatures, freezing, dehydration, various radiations, high osmotic pressure and high concentrations of ethanol and other solvents [29-34]. In our previous studies [35], the results showed that the high alcohol tolerance of the yeast cells of Saccharomyces sp. W0 was dependent of the trehalose content and trehalose in the yeast cells could even protect the integrity of the mitochondrial membrane and prevent the loss of mitochondrial DNA. However, in another study [10], it was also found that high ergosterol and phosphatidylinositol contents in the yeast cells may be responsible for the high alcohol tolerance and high ethanol yield of Saccharomyces sp. W0. It has also been reported that among different wine yeasts tested, $S$. cerevisiae var. capensis flor, with the highest ergosterol concentration in the plasma membrane of its cells, was found to be the most alcohol tolerant when it was shocked with $4.0 \%(v / v)$ alcohol [36]. As ethanol tolerance of the yeast strain 2E00498 was higher than that of Saccharomyces sp. W0, the ethanol tolerance of Saccharomyces sp. W0 could be improved by cell fusion or hybridization between the yeast strain 2E00498 and Saccharomyces sp. W0. This work is being carried out in this laboratory. Such recombinant strains of fusants or hybrids will be useful in the fermentation and biofuel industries.

\section{Conclusions}

In this study, it was found that most of the strains of $S$. cerevisiae in marine environments occurred in the guts and on the surface of marine fish and was not found in sea water and sediments. All the strains of $S$. cerevisiae isolated from the marine environments had a lower ability to produce ethanol than the highly alcohol-producing yeast Saccharomyces sp. W0. However, some of them had higher alcohol tolerance and a higher trehalose content than Saccharomyces sp. W0. Such marine-derived yeast strains with higher ethanol tolerance could be used to further improve the alcohol tolerance of Saccharomyces sp. W0 by cell fusion and hybridization. Fusants with both high alcohol production and high ethanol tolerance could be widely applied in various sectors of biotechnology.

Author Contributions: Conceptualization, Z.C., G.-L.L. and Z.-M.C.; methodology, B.-C.T.; Formal analysis, Z.H.; Resources, Z.-M.C.; data curation, B.-C.T.; writing-original draft preparation, Z.-M.C. and Z.H.; writing - review and editing, all authors; funding acquisition, Z.-M.C. All authors have read and agreed to the published version of the manuscript. 
Funding: This work was supported by National Natural Science Foundation of China (Grant No. 31970058) and the Fundamental Research Funds for the Central Universities (Grant No. 31500029).

Institutional Review Board Statement: Not applicable.

Informed Consent Statement: Not applicable.

Data Availability Statement: The data presented in this study are available on request from the corresponding author.

Acknowledgments: This work was supported by the National Natural Science Foundation of China (Grant No. 31970058) and the Fundamental Research Funds for the Central Universities (Grant No. 31500029).

Conflicts of Interest: The authors declare no conflict of interest.

\section{References}

1. Romano, P.; Capece, A.; Jespersen, L. Taxonomic and ecological diversity of food and beverage yeasts. In The Yeast Handbook, Yeasts in Food and Beverages; Querol, A., Fleet, G.H., Eds.; Springer: Berlin/Heidelberg, Germany, 2006; pp. 20-40.

2. Buzzini, P.; Vaughan-Martini, A. Yeast Biodiversity and Biotechnology. In The Yeast Handbook, Biodiversity and Ecophysiology of Yeasts; Springer: Berlin/Heidelberg, Germany, 2006; pp. 534-559.

3. Chi, Z.M.; Chi, Z.; Zhang, T.; Yue, L.X.; Li, J.; Wang, X.H. Production, characterization and gene cloning of the extracellular enzymes from the marine-derived yeasts and their potential applications. Biotechnol. Adv. 2009, 27, 236-255. [CrossRef]

4. Chi, Z.; Liu, G.L.; Lu, Y.; Jiang, H.; Chi, Z.M. Bio-products produced by marine yeasts and their potential applications. Bioresour. Technol. 2016, 202, 244-252. [CrossRef]

5. Zhang, X.; Hua, M.X.; Song, C.L.; Chi, Z.M. Occurrence and diversity of marine yeasts in Antarctica environments. J. Ocean Univ. China 2012, 11, 70-74. [CrossRef]

6. Wei, X.; Chi, Z.; Liu, G.L.; Hu, Z.; Chi, Z.M. The genome-wide mutation shows the importance of cell wall integrity in growth of the psychrophilic yeast Metschnikowia australis W7-5 at different temperatures. Microb. Ecol. 2021, 81, 52-66. [CrossRef]

7. Nagahama, T. Yeast biodiversity in freshwater, marine and deep-sea environments. In The Yeast Handbook Biodiversity and Ecophysiology of Yeasts; Springer: Berlin/Heidelberg, Germany, 2006; pp. 241-262.

8. Gatesoupe, F.J. Live yeasts in the gut: Natural occurrence, dietary introduction, and their effects on fish health and development. Aquaculture 2007, 267, 20-30. [CrossRef]

9. Tovar-Ramírez, D.; Zambonino, J.; Cahu, C.; Gatesoupe, F.J.; Vázquez-Juárez, R.; Lésel, R. Effect of live yeast incorporation in compound diet on digestive enzyme activity in sea bass (Dicentrarchus labrax) larvae. Aquaculure 2002, 204, 113-123. [CrossRef]

10. Chi, Z.M.; Kohlwein, S.D.; Paltauf, F. Role of phosphatidylinositol (PI) in ethanol production and ethanol tolerance by a high ethanol producing yeast. J. Ind. Microbiol. Biotechnol. 1999, 22, 58-63. [CrossRef]

11. Chi, Z.M.; Tani, Y.; Hayashida, S. Construction of tetraploid cells by protoplast fusion and heat treatment in ethanol tolerant yeasts. Ann. Rep. ICBiotech. 1991, 14, 135-145.

12. Kurtzman, C.P.; Fell, J.W. The Yeast: A Taxonomic Study, 4th ed.; Elsevier: Amsterdam, The Netherlands, 1998 ; pp. 77-107.

13. Sambrook, J.; Fritsch, E.F.; Maniatis, T. Molecular Cloning: A Laboratory Manual, 2nd ed.; Cold Spring Harbor Laboratory: New York, NY, USA, 1989; pp. 367-370. (In Chinese)

14. Chi, Z.M.; Ma, C.; Wang, P.; Li, H.F. Optimization of medium and cultivation conditions for alkaline protease production by the marine yeast Aureobasidium pullulans. Bioresour. Technol. 2007, 98, 534-538. [CrossRef] [PubMed]

15. Gao, L.M.; Chi, Z.M.; Sheng, J.; Wang, L.; Li, J.; Gong, F. Inulinase-producing marine yeasts: Evaluation of their diversity and inulin hydrolysis by their crude enzymes. Microb. Ecol. 2007, 54, 722-729. [CrossRef]

16. Sugita, T.; Takashima, M.; Kodama, M.; Tsuboi, R.; Nishikawa, A. Description of a new yeast species, Malassezia japonica, and its detection in patients with atopic dermatitis and healthy subjects. J. Clin. Microbiol. 2003, 41, 4695-4699. [CrossRef]

17. Tamura, K.; Dudley, J.; Nei, M.; Kumar, S. MEGA4: Molecular evolutionary genetics analysis (MEGA) Software Version 4.0. Mol. Biol. Evol. 2007, 24, 1596-1599. [CrossRef] [PubMed]

18. Wang, J.M.; Zhang, T.; Chi, Z.; Liu, G.L.; Chi, Z.M. 18S rDNA integration of the exo-inulinase gene into chromosomes of the high ethanol producing yeast Saccharomyces sp. W0 for direct conversion of inulin to bioethanol. Biomass Bioenergy 2011, 35, 3032-3039. [CrossRef]

19. Stewart, P.R. Methods in Cell Biology; Prescott, D.M., Ed.; Academic Press: London, UK; New York, NY, USA, 1982; Volume 12, pp. 111-147.

20. JeffWu, C.F.; Hamada, M. Experiments Planning, Analysis and Parameter Design Optimization; John Wiley and Sons: New York, NY, USA, 2000; pp. 23-34.

21. Chi, Z.M.; Liu, Z.R. High-concentration alcoholic production from hydrolysate of raw ground corn by a tetraploid yeast strain. Biotechnol. Lett. 1993, 15, 877-882. [CrossRef]

22. Zhang, T.; Chi, Z.; Chi, Z.M.; Parrou, J.L.; Gong, F. Expression of the inulinase gene from the marine-derived Pichia guilliermondii in Saccharomyces sp. W0 and ethanol production from inulin. Microb. Biotechnol. 2010, 3, 576-582. [CrossRef] [PubMed] 
23. De Araujo, F.V.; Soares, C.A.G.; Hagler, A.N.; Mendonca-Hagler, L.C. Ascomycetous yeast communities of marine invertebrates in a Southeast-Brazillian mangrove ecosystems. Antonie Van Leeuwenhoek 1995, 68, 91-99. [CrossRef] [PubMed]

24. Zaky, A.S.; Greetham, D.; Louis, E.J.; Tucker, G.A.; Du, C.A. New isolation and evaluation method for marine-derived yeast spp. with potential applications in industrial biotechnology. J. Microbiol. Biotechnol. 2016, 26, 1891-1907. [CrossRef] [PubMed]

25. Obara, N.; Okai, M.; Ishida, M.; Urano, N. Bioethanol production from mixed biomass (waste of Undaria pinnatifida processing and paper shredding) by fermentation with marine derived Saccharomyces cerevisiae. Fish Sci. 2015, 81, 771-776. [CrossRef]

26. Zaky, A.S.; French, C.E.; Tucker, G.A.; Du, C. Improving the productivity of bioethanol production using marine yeast and seawater-based media. Biomass Bioenergy 2020, 139, 105615. [CrossRef]

27. Zaky, A.S.; Tucker, G.A.; Du, C. Use of marine yeast for the efficient production of bioethanol from seawater-based media. New Biotechnol. 2016, 33, S52-S53. [CrossRef]

28. Saravanakumar, K.; Senthilraja, P.; Kathiresan, K. Bioethanol production by mangrove-derived marine yeast, Sacchromyces cerevisiae. J. King Saud Univ. Sci. 2013, 25, 121-127. [CrossRef]

29. Obara, N.; Ishida, M.; Hamada-Sato, N.; Urano, N. Efficient bioethanol production from scrap paper shredder by a marine Saccharomyces cerevisiae derived C-19. Stud. Sci. Technol. 2012, 1, 127-132.

30. Hounsa, C.G.; Brandt, E.V.; Thevelein, J.; Hohmann, S.; Prior, B.A. Role of trehalose in survival of Saccharomyces cerevisiae under osmotic stress. Microbiology 1998, 44, 671-680. [CrossRef]

31. Lewis, J.G.; Learmonth, R.P.; Attfield, P.V.; Watson, K. Stress co-tolerance and trehalose content in baking strains of Saccharomyces cerevisiae. J. Ind. Microbiol. Biotechnol. 1997, 18, 30-36. [CrossRef] [PubMed]

32. Mansure, J.J.C.; Panek, A.D.; Crowe, L.M.; Crowe, J.H. Trehalose inhibits ethanol effects on intact yeast cells and liposomes. Biochim. Biophys. Acta 1994, 1191, 309-316. [CrossRef]

33. Panek, A.D. Trehalose metabolism-new horizons in biotechnological applications. Braz. J. Med. Biol. Res. 1995, 28, 169-181. [PubMed]

34. Schick, I.; Haltrich, D.; Kulbe, K.D. Trehalose phosphorylase from Pichia fermentans and its role in the metabolism of trehalose. Appl. Microbiol. Biotechnol. 1995, 43, 1088-1095. [CrossRef]

35. Gao, J.; Chi, Z.M. The relationship between trehalose content and ethanol tolerance in high ethanol tolerant yeast and ethanol sensitive yeast. Food Ferment. Ind. 2001, 27, 4-7.

36. Aguilera, F.; Peinado, R.A.; Millán, C.; Ortega, J.M.; Mauricio, J.C. Relationship between ethanol tolerance, $\mathrm{H}^{+}$-ATPase activity and the lipid composition of the plasma membrane in different wine yeast strains. Int. J. Food Microbiol. $2006,110,34-42$. [CrossRef] [PubMed] 